Серія: Педагогічні науки. - Вип.3. - Бердянськ : БДПУ, 2019. - 453 с.

УДК 378.016:821.161.2]:008:614.253.4

DOI 10.31494/2412-9208-2019-1-3-386-397

\title{
THE PROFESSIONALLY-COMMUNICATIVE COMPETENCY OF A FOREIGN MEDICAL STUDENT
}

\section{ПРОФЕСІЙНО-КОМУНІКАТИВНА КОМПЕТЕНТНІСТЬ ІНОЗЕМНОГО СТУДЕНТА-МЕДИКА}

\author{
Maria TSURKAN, \\ Candidate of Philology Sciences, \\ Associate Professor \\ Higher State Educational \\ Establishment of Ukraine \\ "Bukovynian State Medical \\ University" \\ $\triangle 2$ Theatralna Sq., \\ Chernivtsi, Ukraina, 58002
}

https://orcid.org/0000-0003-2866-1743

maria-ts77@ukr.net
Марія ЦУРКАН,

кандидат філологічних наук, доцент

Original manuscript received: October 14, 2019

Вищий державний навчальний заклад України

"Буковинський державний медичний університет"

$\triangle$ пл. Театральна, 2

м. Чернівці, Україна, 58002

Revised manuscript accepted: December 12, 2019

\begin{abstract}
Aim of investigation - to describe and outline the content of such concepts as "competence", "competency", "communicative competency", "professional competency", "professionally-communicative competency" of a foreign student-medic under conditions of inter-ethnic cultural communication. Methodology of investigation - is based on complex combination of theoretical methods of applied linguistics, psycho-linguistics, linguo-didactics with the aim of definition of conceptual principles of the investigation. Scientific novelty of the investigation consists in the attempt of holistic comprehension of linguistic category "professionally-communicative competency» of a foreign student-medic. Conclusions. It has been determined, that competence - is integrated quality (attribute) or complex characteristic of a personality, that combines desire, readiness and ability to implement activity (to achieve set goal, solve problems, adjust tasks, analyze situation, make decisions, control personal and unfamiliar actions, qualified and creatively realize the potential, etc.) in a certain professional sphere; on the basis of previously gained competencies; competency - is a complex of knowledge, imaginations, skills, habits and attitudes that are formed in the process of education and are applied in a certain sphere of activity; professional competency - complex of knowledge from professionally-oriented disciplines (anatomy, physiology, histology, pharmacology, etc.) and ability to practically apply them in professional activity. It has been investigated, that professionally-communicative competency of a foreign studentmedic - is a complicated psychologically-pedagogical category, that on our opinion integrates professional knowledge (collecting anamnesis, recognition of the disease and setting a diagnosis, prescribing treatment, etc.), independent and creative composition of thinking (ability to analyze the process, efficiency and final result of a treatment; ability to evaluate not only achievement in personal work, but to see the reasons of failures), communicative skills (possessing of generally used and professional vocabulary, correct and relevant selection of language tools, logical and consistent building of expression, appropriate diction, ability to
\end{abstract}


listen, arrangement of medical documents: references, protocol of a surgery, medical case or an abstract, etc.), moral values (tolerance, tactfulness, patience, sensitiveness, empathy, politeness, cordiality, benevolence, etc.).

Key words: competence, competency, communicative, professional, professionally-communicative competency, foreign student-medic.

Вступ. Основне завдання медичних закладів вищої освіти України (МЗВОУ) - підготовка конкурентоспроможних фахівців, які мають належний рівень професійно-комунікативної компетентності, тобто володіють системою професійних знань, комунікативних умінь і навичок. Одним із пріоритетних напрямів методики викладання української мови як іноземної МЗВОУ є підвищення якості навчання іноземних студентівмедиків, зокрема їхньої готовності до професійного спілкування з метою надання медичної допомоги.

Аналіз попередніх досліджень i публікацій. Формування комунікативної компетентності студентів різних спеціальностей описано в працях мовознавців (Ф. Бацевич, І. Гальперін, Т. Єщенко, І. Кочан, М. Крупа, Л. Мацько, В. Олексенко, М. Плющ, Л. Руденко, Л. Синельникова та ін.), лінгводидактів (3. Бакум, А. Богуш, М. Вашуленко, Є. Голобородько, Н. Голуб, О. Горошкіна, І. Дроздова, Т. Донченко, С. Караман, К. Климова, В. Мельничайко, Г. Михайловська, А. Нікітіна, М. Пентилюк, Л. Рускуліс, Т. Симоненко, В. Статівка, Г. Шелехова та ін.), психологів і психолінгводидактів (Л. Виготський, І. Зимня та ін.), де зазначено, що правильність, логічність, виразність, образність, точність, багатство мовлення, його доцільність і доречність впливають на загальний емоційний фон, сприяють зацікавленості процесом спілкування. Питанням профресійної комунікації фахівців різних спеціальностей займалися К. Балабанова, Н. Бідюк, В. Борисенко, Л. Дідух, Ю. Дробязко, О. Каверіна, О. Коваленко, О. Ковтун, О. Краєвська, Г. Онкович, О. Семеног, Н. Тоцька, Н. Формановська, С. Хаджирадєва ін.

Сьогодні особливу увагу науковців звернено на проблеми формування профресіоналізму фахівців медичного профілю (Доник, 2009), професійно значущих, комунікативних якостей майбутніх лікарів (Кубіцький, 2019); професійно-мовленнєвої компетентності майбутніх лікарів (Варданян, 2017), методику навчання профресійного російського мовлення студентів-іноземців вищого медичного закладу (Васецька, 2005), професійного мовлення майбутніх медичних працівників у вищих медичних навчальних закладах (Лісовий, 2006), підготовку майбутніх іноземних спеціалістів-медиків до професійного спілкування (Рагріна, 2017), розвиток компетентностей міжкультурної комунікації студентів-іноземців на основному етапі навчання української мови (Костюк, 2018), формування полікультурної компетентності у студентів-медиків у навчально-виховному процесі вищого медичного навчального закладу (Щербакова, 2015) та ін.

Мета нашого дослідження - окреслити зміст поняття «професійно-комунікативна компетентність іноземного студента-медика» (ПККІСМ) шляхом узагальнення теоретичних здобутків українських і закордонних дослідників. 
Серія: Педагогічні науки. - Вип.3. - Бердянськ : БДПУ, 2019. - 453 с.

Як відомо, професія лікаря належить до професій типу “людина людина", тому фаховий рівень спеціаліста-медика залежить від його комунікативної компетентності, формування якої відбувається насамперед на заняттях із української мови як іноземної. Уміння спілкуватися з пацієнтом - запорука бажаного результату в процесі лікування, адже комунікування у цьому випадку допомагає лікареві отримати необхідну інформацію, зокрема зібрати анамнез, з'ясувати стан здоров'я пацієнта, підтримати та заспокоїти його, зняти напругу і хвилювання, подолати тривогу і страх, а також сформулювати рекомендації та вказівки, дати поради родичам тощо. Отже, усі зазначені дії лікаря, зокрема іноземного медика, є складовими його комунікативної компетентності, яка разом із професійною компетентністю забезпечують надання якісної медичної допомоги пацієнтові.

Компетентність (від лат. competens (competentis) - належний, відповідний), за матеріалами словника іншомовних слів, означає поінформованість, обізнаність, авторитетність (Словник іншомовних слів, 2000: 282).

Закон України "Про вищу освіту" визначає компетентність як “...динамічну комбінацію знань, умінь і практичних навичок, способів мислення, професійних, світоглядних і громадянських якостей, моральноетичних цінностей, яка визначає здатність особи успішно здійснювати професійну та подальшу навчальну діяльність і $€$ результатом навчання на певному рівні вищої освіти” (Закон України “Про вищу освіту”, 2014).

У методичних рекомендаціях щодо розроблення стандартів вищої освіти Департаменту вищої освіти (м. Київ) зазначено, що компетентність динамічна комбінація знань, вмінь, навичок, способів мислення, поглядів, цінностей, інших особистих якостей, яка визначає здатність особи успішно соціалізуватися, провадити професійну та/або подальшу навчальну діяльність (Методичні рекомендації щодо розроблення стандартів вищої освіти, 2017).

Термін "компетентність", на думку А. Хуторського, - це особистісна якість, або сукупність якостей та мінімальний досвід, які вже склалися щодо діяльності в певній галузі; за визначенням Р. Мільруда, - це комплексний особистісний ресурс, який забезпечує можливість ефективної взаємодії 3 довкіллям у тій чи іншій галузі; І. Ґудзик вважає, що це уміння та знання, необхідні для ефективного виконання дій (Черних, 2010).

М. Головань розкриває зміст цього поняття комплексно: "компетентність - це володіння компетенцією, що виявляється в ефективній діяльності і включає особисте ставлення до предмету і продукту діяльності; компетентність - це інтегративне утворення особистості, що інтегрує в собі знання, уміння, навички, досвід i особистісні властивості, які обумовлюють прагнення, здатність i готовність розв'язувати проблеми і завдання, що виникають в реальних життєвих ситуаціях, усвідомлюючи при цьому значущість предмету і результату діяльності" (Головань, 2008: 29).

Більшість науковців пояснює компетентність як результат набуття 
компетенцій. Зокрема, дослідники Інституту педагогічної освіти і освіти дорослих НАПН України, вважають, що "компетентність - це результат набуття людиною компетенцій, які дають їй змогу якісно виконувати трудові функції, успішно засвоювати знання, взаємодіяти з іншими людьми в різних ситуаціях, швидко адаптуватися до змін у профессійній діяльності, набувати соціальної самостійності" (Компетентнісний підхід до підготовки педагогів у зарубіжних країнах : теорія та практика, 2014; 17).

Як бачимо, компетентність - це інтегрована якість (властивість) або комплексна характеристика особистості, що поєднує в собі бажання, готовність і здатність здійснювати діяльність (досягати поставленої мети, вирішувати проблеми, розв'язувати завдання, аналізувати ситуацію, приймати рішення, контролювати як власні, так і чужі дії, кваліфріковано та креативно реалізовувати потенціал тощо) у певній професійній сфрері; на основі попередньо набутих компетенцій.

Що ж до поняття "компетенція", то слушним вважаємо визначення І. Зимньої, яка зауважує, що компетенції - це деякі внутрішні, потенційні, психологічні новоутворення (знання, програми, алгоритми дій, цінності та відносини), які потім виявляються у компетентностях людини у якості актуальних і діяльнісних проявів. Тобто компетентності - це подальший особистісний і поведінковий прояви компетенцій (Зимня, 2006).

В Енциклопедії освіти компетенція, на думку української дослідниці Н. Бібік, - це "відчужена від суб'єкта, наперед задана соціальна норма (вимога) до освітньої підготовки учня, необхідна для його якісної продуктивної діяльності в певній сфері, тобто соціально закріплений результат" (Енциклопедія освіти, 2008: 409). Також у цій розвідці зазначено, що компетентність $€$ результатом набуття компетенцій, яка на відміну від них включає особистісну характеристику й ставлення до предмета діяльності.

О. Сисоєва вважає, що компетенція - це визначена норма стосовно неперервної освіти, яка задається освітніми стандартами і використовується для формування вимог до результатів навчання. Компетентність - це інтегрована особистісна якість особи (ії капітал), яка формується на етапі навчання, остаточно сформовується і розвивається у процесі практичної діяльності та забезпечує компетентний підхід до вирішення професійних завдань. Компетентність $€$ оцінною характеристикою особи. Компетентності особи $є$ іï особистісним капіталом і результатом навчання у різних формах фоомальної, неформальної та інформальної освіти (Сисоєва, 2015: 8).

Представлений вище аналіз визначень досліджуваного поняття вказує на те, що компетенція - це сукупність знань, уявлень, умінь, навичок i ставлень, що формуються в процесі навчання та застосовуються в певній сфері діяльності.

Однією 3 ключових компетентностей фахівця будь-якої галузі $€$ комунікативна компетентність, яка передбачає володіння державною мовою, а також здатність спілкуватися насамперед рідною мовою, відтак обов'язково державною мовою, а потім іншими іноземними мовами. На 
думку Ю. Ємельянова, комунікативна компетентність - це заснована на знаннях та чуттєвому досвіді здатність особистості орієнтуватися в ситуаціях спілкування, вільно володіти вербальними і невербальними засобами спілкування. Дослідник наголошує на тому, що така здатність передбачає соціально-психологічне навчання, тобто подальшу можливість навчатися спілкуванню. Комунікативна компетентність, вважає науковець, виявляється також в умінні людини організовувати так званий міжособистісний простір у процесі ініціативного й активного спілкування 3 людьми. Ю. Ємельянов підкреслює, що комунікативна компетентність завжди набувається в соціальному контексті (Емельянов, 1999).

Л. Пиріг розглядає комунікативну компетентність як сукупність знань про спілкування в різноманітних умовах та 3 різними комунікантами, а також уміння їх ефективного застосування у конкретному спілкуванні в ролі адресанта і адресата. Сформованість цієї якості у майбутніх лікарів передбачає володіння мовленнєвими уміннями й навичками, необхідними для спілкування, сукупність знань про норми й правила ведення комунікації (Пиріг, 1998: 51).

Комунікативна компетентність лікаря розуміється як інтегральна якість особистості (сукупність когнітивних, емоційних і поведінкових особливостей) та базується на вмінні продуктивно спілкуватися 3 пацієнтами та іншими учасниками лікувально-профілактичного процесу, уникаючи конфліктних ситуацій, будувати конструктивні відносини. Крім того, це поняття включає в себе володіння певною культурою спілкування, поведінки (Васільєва, 2009: 173).

Досліджуючи комунікативну компетентність іноземного студентамедика, звертаємо увагу на те, що ця компетентність базується на взаємодії трьох мовних систем, а саме: рідної мови, англійської та української. Як бачимо, формування комунікативної компетентності іноземного лікаря - складне, багаторівневе лінгвістично-психологічносоціальне явище, яке, на відміну від процесу формування комунікативної компетентності українського студента, потребує не лише фахових (спеціальних) знань, а й створення та впровадження методичної системи навчання української мови як іноземної у медичних закладах вищої освіти. У Програмі з української мови як іноземної (Київ, 2017 р.) відповідно до Стандартів вищої освіти України, навчального плану та освітньо-професійної програми вищої освіти підготовки фахівців, зміст комунікативної компетентності аналізують за такими показниками:

\begin{tabular}{|c|c|l|l|l|}
\hline $\begin{array}{c}\text { Компетент } \\
\text {-ність }\end{array}$ & Знання & \multicolumn{1}{|c|}{ Уміння } & \multicolumn{1}{|c|}{ Комунікація } & \multicolumn{1}{|c|}{$\begin{array}{c}\text { Автономія та } \\
\text { відповідальність }\end{array}$} \\
\hline Комуні & Знання & Уміння & Здатність & Досвід \\
кативна & вербальних і & доцільно & встановлювати і & особистої \\
компете & невербальни & використовуват & підтримувати & відповідальнос \\
нтність & х засобів і & и засоби мови & контакт зі & ті за власну \\
& способів & в практиці & співрозмовнико & комунікативну \\
& висловлення & живого & М, змінювати & поведінку; \\
& думок, & спілкування, & мовленнєву & вимогливість \\
& почуттів у & виправдано & поведінку & до власного \\
& різних & добирати & залежно від & мовлення та \\
\hline
\end{tabular}




\begin{tabular}{|c|c|l|l|l|}
\hline сорерах & вербальні та & комунікативної & культури \\
спілкування & невербальні & ситуації & \\
відповідно до & засоби для & & \\
ситуацій і тем & вирішення тих & & \\
спілкування, & чи інших & & \\
мовленнєвих & комунікативних & & \\
актів, & завдань у & & \\
інтенційних & різних сферах і & & \\
програм, & ситуаціях & & \\
типів & спілкування & & \\
комунікативн & & & \\
ої організації & & & \\
дискурсу & & & \\
тощо & & & \\
\hline
\end{tabular}

Передумовою формування комунікативної компетентності медикаіноземця $€$ його адаптація в українськомовному середовищі, вивчення української мови, культури, історії, побуту, національних звичаїв і традицій українців. Розглядаючи проблеми навчання української мови як іноземної, 3. Бакум наголошує на необхідності формування спільних уявлень про світ у соціально-психологічному та культурному вимірах. Задля ефективного вивчення мови необхідно аналізувати поняттєву модель нації з урахуванням її культури, орієнтацією на загальнолюдські цінності, розвиток крос-культурного світогляду, створення умов для усвідомлення індивідуальності, специфічності рідної мови та мови, яку вивчають (Бакум, 2010: 226-232).

Отже, комунікативна компетентність іноземного студентамедика - лінгвістична категорія, що інтегрує в собі знання вербальних і невербальних мовних засобів, уміння та навички доречно використовувати їх в процесі комунікації з метою встановлення мовного контакту зі співрозмовником, подолання комунікативного бар'єру; комунікативна компетентність забезпечує адаптацію людини в соціумі, її особистісне та професійне зростання, можливість планувати, сприймати, оцінювати, регулювати та коригувати процес спілкування.

Паралельно із комунікативною компетентністю студентів-медиків із інших країн, які здобувають вищу медичну освіту в Україні, відбувається формування їх професійної компетентності.

Поняття "професійна компетентність" розглядали вітчизняні (Н. Бібік, Я. Кодлюк, О. Овчарук та ін.) й зарубіжні (О. Бобієнко, Е. Зеєр, Ф. Кіргуєва та ін.) науковці. Разом із тим аналіз публікацій показує, що чіткого визначення структури професійної компетентності майбутніх медичних фахівців роботи досі немає.

Профресійна компетентність передбачає: усвідомлення особистісних потягів до діяльності, потреб та інтересів; прагнення і ціннісні орієнтації; мотивів діяльності; уявлення про свої соціальні ролі; самооцінку особистісних властивостей і якостей, професійних знань, умінь і навичок, професійно важливих якостей; регулювання свого професійного становлення. Отже, професійна компетентність фахівця $€$ інтегративною властивістю особистості, що визначає здатність фахівця здійснювати 
професійну діяльність на найвищому рівні (Сисоєва, 2012: 156).

Колектив науковців Інституту педагогічної освіти і освіти дорослих НАПН України пропонують таке визначення: “Професійна компетентність це базова характеристика діяльності фахівця, яка включає як змістовий (знання), так і процесуальний (уміння) компоненти, і має головні суттєві ознаки, а саме: мобільність знань, гнучкість методів професійної діяльності і критичність мислення" (Компетентнісний підхід до підготовки педагогів у зарубіжних країнах : теорія та практика, 2014: 25).

Ми розглядаємо профресійну компетентність як сукупність знань із професійно орієнтованих дисциплін (анатомія, фрізіологія, гістологія, фрармакологія тощо) і вмінь їх практично використовувати в професійній діяльності.

Виходячи зі змісту понять компетенція, компетентність, комунікативна компетентність і профресійна компетентність, окреслимо суть професійно-комунікативної компетентності як інтегрованої категорії, що $€$ показником сфрормованості системи професійних знань, комунікативних умінь і навичок, ціннісних орієнтацій, загальної гуманітарної культури, інтегральних показників культури мовлення, необхідних для якісної професійної діяльності

На думку В. Погрібної, формування професійної комунікативної компетентності передбачає: глибокі профресійні знання і оволодіння понятійно-категоріальним апаратом певної професійної сфери та відповідною системою термінів; вміле професійне використання мовних стилів і жанрів відповідно до місця, часу, обставин, статусно-рольових характеристик партнера (партнерів); знання етикетних мовних формул і вміння ними користуватися у професійному спілкуванні; вміння знаходити, вибирати, сприймати, аналізувати та використовувати інформацію профрільного спрямування; володіння інтерактивним спілкуванням, характерною ознакою якого є необхідність миттєвої відповідної реакції на повідомлення чи інформацію, що знаходиться в контексті попередніх повідомлень; володіння основами риторичних знань і вмінь; уміння оцінювати комунікативну ситуацію швидко і на високому професійному рівні приймати рішення та планувати комунікативні дії (Погрібна, 2008: 230).

А. Варданян зазначає, що робота лікаря передбачає чималу кількість міжособистісних контактів. Від професійно-мовленнєвої компетентності лікаря залежить ефрективність та успішність спілкування з пацієнтами, рідними, колегами. Комунікативна взаємодія допомагає вдалому вирішенню проблем учасниками комунікації і сприяє досягненню цілей лікування i взаєморозуміння між лікарем і хворим (Варданян, 2017: 12).

Спеціаліст-медик має бути освіченим, конкурентоздатним, мобільним, самостійним у прийнятті рішень, відповідальним за результати своєї діяльності, гармонійно розвиненим, повинен володіти науковим стилем мислення, уявленнями про природничо-наукову картину світу, розвивати критичне мислення, усвідомлювати свою подальшу діяльність умовах високотехнологічного суспільства в гармонії 3 навколишнім середовищем, засвоювати методи науково пізнання й 
формування науково світогляду. Медичні працівники повинні також усвідомлювати покладену на них відповідальність, бути доброзичливими, уважними до хворого, привітними і витриманими. Важливим $\epsilon$ зацікавленість медичного фахівця своєю професією, любов до неї, терпіння і цілеспрямованість, поєднання рішучості 3 обачливістю (Рагріна, 2017:. 35-36; Колісник-Гуменюк, 2015).

Формування професійно-комунікативної компетентності іноземного студента-медика, окрім описаних вище вимог і якостей, відбувається через подолання низки бар'єрів, серед яких мовний і психологічний, що спостережено у спілкуванні не лише з викладачами, а й з пацієнтами та їхніми родичами. Також у процесі професійної комунікації між студентоміноземцем і українським адресатом непорозуміння виникають через індивідуально-психологічні особливості адресанта, які залежать від його расової, етнічної, релігійної та гендерної приналежності.

Як зауважують лікарі-практики, "студент із країн Південного Сходу та Східної Азії нерідко відмовляється спілкуватися та обстежувати дівчинкупідлітка, яка і одягнута нескромно, на його погляд, і поводить себе зухвало, оголюючи тіло для обстеження (перкусії та аускультації і т. ін.). Студенти 3 Індії та афрриканських країн часто бояться насильства, ксенофобських настроїв з боку інших студентів, хворих та їх батьків у палаті під час фрізикального обстеження тощо. Нерідко мають місце сварки та суперечності в межах різних культур, як от між вихідцями з Туркменістану, Казахстану та африканських країн тощо" (Сучасний стан , 2018: 75).

Із метою формування професійно-комунікативної компетентності іноземного студента-медика потрібно інформувати його про основи законодавства України у сфрері освіти, його права та обов'язки як студента медичного закладу вищої освіти відповідно до Положення чи статуту навчального закладу, Кодексом честі медичного працівника. Саме роз'яснювальна робота попередить виникнення конфрліктів і непорозумінь між студентами-медиками як представниками чужих культур і українськими пацієнтами, які інколи демонструють низький рівень загальної культури та упередженість щодо іноземця, зокрема іноземного студента чи лікаря.

Висновки. Отже, професійно-комунікативна компетентність іноземного студента-медика - складна лінгвістично-педагогічна категорія, яка, на нашу думку, інтегрує в собі профресійні знання (знання з медичних дисциплін, збір анамнезу, розпізнавання захворювання й встановлення діагнозу, призначення лікування тощо), самостійний та творчий склад мислення (навички аналізувати процес, ефективність і кінцевий результат лікування; уміння оцінити не лише досягнення у своїй роботі, але й побачити причини невдач), комунікативні уміння (володіння загальновживаною та професійною лексикою, правильний і доречний добір мовних засобів, логічна і послідовна побудова висловлювання, відповідна дикція, вміння слухати, оформлення медичних документів: довідок, протоколу операції, історії хвороби чи реферату тощо), моральні цінності (толерантність, тактовність, інтелігентність, терпіння, чуйність, співпереживання, толерантність, ввічливість, привітність, доброзичливість тощо). 


\section{Література}

1. Бакум 3. П. Українська мова як іноземна: Лінгводидактичні проблеми / 3. Бакум // Філологічні студії: Науковий вісник Криворізького державного педагогічного університету : зб. наук. праць. - 2010. - Вип. 5. - С. 226-232.

2. Варданян А. О. Формування професійно-мовленнєвої компетентності майбутніх лікарів : дис. ...канд. пед. наук / Полтавський національний педагогічний університет імені В. Г. Короленка. - Хмельницький. - 2017. - 289 с.

3. Васецька Л. І. Методика навчання професійного російського мовлення студентів-іноземців вищого медичного закладу: дис. канд. наук / Херсонський державний університет. - Херсон. - 2005. - 296 с.

4. Васильева Л.Н. Коммуникативная компетентность и совладающее поведение будущих врачей / Л.Н.Васильева // Вестник КГУ им. Н.А.Некрасова. 2009. - Т. 15. - № 5. - С.172-176

5. Головань М. С. Компетенція і компетентність: досвід теорії, теорія досвіду / М. С. Головань // Вища освіта України. - 2008. - № 3. - С. 23 - 30.

6. Доника А. Д. Профессиональный онтогенез: Медико-социологические и психолого-этические проблемы врачебной деятельности / А.Д.Доника. - М.: Академия Естествознания. - 2009. - 300 с

7. Емельянов Ю.Н. Теория формирования и практика совершенствования коммуникативной компетентности // Ю. Н. Емельянов. - СПб, 1999. - 403 c.

8. Енциклопедія освіти / [Акад. пед. наук України / гол. Ред. В.Г. Кремень]. - К.: Юрінком Інтер. - 2008. - 1040

9. Закон України «Про вищу освіту» від 01.07.2014 № 1556-VII // Голос України. - 2014. -№ 148 (06.08.2014)

10. Зимняя И. А. Личностная и деятельностная направленность компетентностей как результат современного образования / И.А. Зимняя // Компетентность и проблемы ее формирования в системе непрерывного образования (школа - вуз - послевузовское образование): сб. науч. работ по материалам XVI научно-методической конференции «Актуальные проблемы качества образования и пути их решения». - М.: Исследовательский центр проблем качества подготовки специалистов. - 2006. - 130 с.

11. Колісник-Гуменюк Ю. І., Гуменюк В. В. Особистісна характеристика медичного працівника. Неперервна професійна освіта: теорія і практика. -2015. Вип. 1-2. - С. 72-77

12. Компетентнісний підхід до підготовки педагогів у зарубіжних країнах : теорія та практика : монографія / Н. М. Авшенюк, Т. М. Десятов, Л. М. Дяченко, Н. О. Постригач, Л. П. Пуховська, О. В. Сулима]. - Кіровоград : Імекс-ЛТД. - 2014. $280 \mathrm{c}$.

13. Костюк С. С. Розвиток компетентностей міжкультурної комунікації студентів-іноземців на основному етапі навчання української мови: дис. ...канд. пед. наук / Державний вищий навчальний заклад «Криворізький державний педагогічний університет». - Кривий Ріг. - 2018. - 292 с.

14. Кубіцький С. О. Особливості професійної комунікативної взаємодії майбутніх медпрацівників / С.О.Кубіцький, Н.В.Неділька // Вісник Національної академії оборони. Питання педагогіки. - 2010. - № 2(15). - С.55

15. Лісовий М. І. Формування професійного мовлення майбутніх медичних працівників у вищих медичних навчальних закладах : дис. ...канд. пед. наук / Вінницький державний педагогічний університет імені Михайла Коцюбинського. Вінниця. - 2006. - 192 с.

16. Методичні рекомендації щодо розроблення стандартів вищої освіти. Затверджено Міністерством освіти і науки України (наказ Міністерства освіти і 
науки України від 01.06.2017, № 600). - Киї̈в. - 2017. - 29 с.

17. Пиріг Л. А. Медицина і українське суспільство: зб. мед. публіц. пр. / Л.А.Пиріг. - К. : Б. в., 1998. - 472 с

18. Погрібна В. Л. Соціологія професіоналізму: монографія / В.Л.Погрібна. - К.: Алерта: КНТ: ЦУЛ. - 2008. - 336 с.

19. Примірна Програма навчальної дисципліни «Українська мова як іноземна» підготовки фахівців другого (магістерського) рівня вищої освіти галузі знань 22 «Охорона здоров'я» / уклад. зав каф., проф. С. Луцак та ін. - Київ, 2017. - 196 с.

20. Рагріна Ж. М. Підготовка майбутніх іноземних спеціалістів-медиків до професійного спілкування: дис. ...канд. пед. наук / Запорізький національний ун-т. Запоріжжя. - 2017. - 298 с.

21. Сисоєва С. О. Проблеми неперервної професійної освіти: тезаурус наукового дослідження: наук. видання / С. О. Сисоєва, І. В. Соколова / НАПН України. Ін-т педагогічної освіти і освіти дорослих, МОН. Маріупольський держ. Гуманітарний ун-т. - К.: Видавничий Дім «ЕКМО». - 2012. - 362 с.

22. Сисоєва С. О. «Компетентнісно зорієнтована вища освіта: формування наукового тезаурусу» формування наукового тезаурусу» [Електронний ресурс] Режим доступу: http://elibrary.kubg.edu.ua/9864/1/Sysoeva\%20S.A.\%202015.pdf

23. Словник іншомовних слів / Уклад.: С. М. Морозов, Л. М. Шкарапута. К.: Наукова думка. $-2000 .-680$ с.

24. Сучасний стан та перспективи підготовки лікарів-інтернів у Харківському національному медичному університеті: матеріали 44-ї науковометодичної конференції з інтернатури / кол. авт. - Харків: ХНМУ. - 2018. - 100 с.

25. Черних І. Висвітлення поняття „мовленнєва компетентність” у сучасній лінгвістиці / І. Черних // Вісник ЛНУ імені Тараса Шевченка. - 2010. - Ч. 2. - № 22 (209). - C. 38-44.

26. Щербакова А. В. Формування полікультурної компетентності у студентів-медиків у навчально-виховному процесі вищого медичного навчального закладу: дис. ...канд. пед. наук / Державний заклад «Луганський національний університет імені Тараса Шевченка». - Старобільськ. - 2015. - 357 с.

\section{References}

1. Bakum Z.P. (2010). Ukrainska mova yak inozemna: Linhvodydaktychni problemy. Filolohichni studii: Naukovyi visnyk Kryvorizkoho derzhavnoho pedahohichnoho universytetu : zb. nauk. prats. Vyp. 5. S. 226-232. [in Ukrainian].

2. Vardanian A. O. (2017). Formuvannia profesiino-movlennievoi kompetentnosti maibutnikh likariv : dys. ...kand. ped. nauk / Poltavskyi natsionalnyi pedahohichnyi universytet imeni V. H. Korolenka. Khmelnytskyi. 289 s. . [in Ukrainian].

3. Vasetska L. I. (2005). Metodyka navchannia profesiinoho rosiiskoho movlennia studentiv-inozemtsiv vyshchoho medychnoho zakladu: dys. kand. nauk / Khersonskyi derzhavnyi universytet. Kherson. 296 s. [in Ukrainian].

4. Vasyleva L. N. (2009). Kommunykatyvnaia kompetentnost y sovladaiushchee povedenye budushchykh vrachei. Vestnyk KHU ym. N.A.Nekrasova. T. 15. № 5. S.172-176. [in Russian].

5. Holovan M. S. (2008). Kompetentsiia i kompetentnist: dosvid teorii, teoriia dosvidu. Vyshcha osvita Ukrainy. № 3. S. 23 - 30. [in Ukrainian].

6. Donyka A. D. (2009). Professyonalnыi ontohenez: Medykosotsyolohycheskye y psykholoho-эtycheskye problemb vrachebnoi deiatelnosty. M.: Akademyia Estestvoznanyia. 300 s. [in Russian].

7. Emelianov Yu. N. (1999). Teoryia formyrovanyia y praktyka sovershenstvovanyia kommunykatyvnoi kompetentnosty . SPb. $403 \mathrm{~s}$. [in Russian].

8. Entsyklopediia osvity (2008). [Akad. ped. nauk Ukrainy. hol. Red. V.H. 
Kremen]. K.: Yurinkom Inter. 1040 s. [in Ukrainian].

9. Zakon Ukrainy «Pro vyshchu osvitu» vid 01.07.2014 1556-VII (2014). Holos Ukrainy. № 148 (06.08.2014). [in Ukrainian].

10. Zymniaia Y. A. (2006). Lychnostnaia y deiatelnostnaia napravlennost kompetentnostei kak rezultat sovremennoho obrazovanyia. Kompetentnost y problemb ee formyrovanyia $v$ systeme neprerbvnoho obrazovanyia (shkola - vuz poslevuzovskoe obrazovanye): sb. nauch. rabot po materyalam XVI nauchnometodycheskoi konferentsyy «Aktualnыe problemы kachestva obrazovanyia y puty ykh reshenyia». - M.: Yssledovatelskyi tsentr problem kachestva podhotovky spetsyalystov. 130 s. [in Russian].

11. Kolisnyk-Humeniuk Yu. I., Humeniuk V. V. (2015). Osobystisna kharakterystyka medychnoho pratsivnyka. Neperervna profesiina osvita: teoriia $i$ praktyka. Vyp. 1-2. S. 72-77. [in Ukrainian].

12. Kompetentnisnyi pidkhid do pidhotovky pedahohiv u zarubizhnykh krainakh : teoriia ta praktyka : monohrafiia (2014). N. M. Avsheniuk, T. M. Desiatov, L. M. Diachenko, N. O. Postryhach, L. P. Pukhovska, O. V. Sulyma]. Kirovohrad : Imeks-LTD. 280 s. [in Ukrainian].

13. Kostiuk S. S. (2018). Rozvytok kompetentnostei mizhkulturnoi komunikatsii studentiv-inozemtsiv na osnovnomu etapi navchannia ukrainskoi movy: dys. ...kand. ped. nauk / Derzhavnyi vyshchyi navchalnyi zaklad «Kryvorizkyi derzhavnyi pedahohichnyi universytet». Kryvyi Rih. 292 s. [in Ukrainian].

14. Kubitskyi C. O. (2010). Osoblyvosti profesiinoi komunikatyvnoi vzaiemodii maibutnikh medpratsivnykiv. Visnyk Natsionalnoi akademii oborony. Pytannia pedahohiky. - № 2(15). - S.55. [in Ukrainian].

15. Lisovyi M. I. (2006). Formuvannia profesiinoho movlennia maibutnikh medychnykh pratsivnykiv u vyshchykh medychnykh navchalnykh zakladakh : dys. ...kand. ped. nauk / Vinnytskyi derzhavnyi pedahohichnyi universytet imeni Mykhaila Kotsiubynskoho. Vinnytsia. 192 s. [in Ukrainian].

16. Metodychni rekomendatsii shchodo rozroblennia standartiv vyshchoi osvity (2017). Zatverdzheno Ministerstvom osvity i nauky Ukrainy (nakaz Ministerstva osvity i nauky Ukrainy vid 01.06.2017, № 600). Kyiiv. 29 s. [in Ukrainian].

17. Pyrih L. A. (1998). Medytsyna i ukrainske suspilstvo: zb. med. publits. pr. K. : B. v. -472 s. [in Ukrainian].

18. Pohribna V. L. (2008). Sotsiolohiia profesionalizmu : monohrafiia. K.: Alerta: KNT: TsUL. 336 s. [in Ukrainian].

19. Prymirna Prohrama (2017) navchalnoi dystsypliny «Ukrainska mova yak inozemna» pidhotovky fakhivtsiv druhoho (mahisterskoho) rivnia vyshchoi osvity haluzi znan 22 «Okhorona zdorovia» / uklad. zav kaf., prof.S. Lutsak ta in. Kyiv, 196 s. [in Ukrainian].

20. Rahrina Zh. M. (2017). Pidhotovka maibutnikh inozemnykh spetsialistivmedykiv do profesiinoho spilkuvannia: dys. ...kand. ped. nauk / Zaporizkyi natsionalnyi un-t. Zaporizhzhia. 298 s. [in Ukrainian].

21. Sysoieva S. O. (2012). Problemy neperervnoi profesiinoi osvity: tezaurus naukovoho doslidzhennia: nauk. Vydannia. NAPN Ukrainy. In-t pedahohichnoi osvity i osvity doroslykh, MON. Mariupolskyi derzh. Humanitarnyi un-t. K.: Vydavnychyi Dim «EKMO». [in Ukrainian].

22. Sysoieva, S. O. (2015). «Kompetentnisno zoriientovana vyshcha osvita: formuvannia naukovoho tezaurusu» formuvannia naukovoho tezaurusu» [Elektronnyi resurs] Rezhym http://elibrary.kubg.edu.ua/9864/1/Sysoeva\%20S.A.\%202015.pdf . [in Ukrainian].

23. Slovnyk inshomovnykh sliv (2000). Uklad.: S. M. Morozov, L. M. Shkaraputa. K.: Naukova dumka. 680 s. [in Ukrainian]. 
24. Suchasnyi stan ta perspektyvy pidhotovky likariv-interniv u Kharkivskomu natsionalnomu medychnomu universyteti (2018): materialy 44-yi naukovo-metodychnoi konferentsii z internatury / kol. avt. Kharkiv: KhNMU. 100 s. [in Ukrainian].

25. Chernykh I. (2010). Vysvitlennia poniattia „movlennieva kompetentnist” u suchasnii linhvistytsi. Visnyk LNU imeni Tarasa Shevchenka. Ch. 2. № 22 (209). S. 3844. [in Ukrainian].

26. Shcherbakova A. V. (2015). Formuvannia polikulturnoi kompetentnosti u studentiv-medykiv u navchalno-vykhovnomu protsesi vyshchoho medychnoho navchalnoho zakladu: dys. ...kand. ped. nauk / Derzhavnyi zaklad «Luhanskyi natsionalnyi universytet imeni Tarasa Shevchenka». Starobilsk. 357 s. [in Ukrainian].

\begin{abstract}
АНОТАЦІЯ
Мета дослідження - описати та окреслити зміст понять "компетенція", "компетентність", "комунікативна компетентність", "профресійна компетентність", "профресійно-комунікативна компетентність", іноземного студента-медика в умовах міжетнічного культурного спілкування. Методологія дослідження грунтується на комплексному поєднанні теоретичних методів прикладної лінгвістики, психолінгвістики, лінгводидактики з метою визначення концептуальних положень дослідження. Наукова новизна статmі полягає у спробі цілісного осмислення лінгвістичної категорії "профресійно-комунікативна компетентність" іноземного студента-медика. Висновки. Встановлено, що компетентність - це інтегрована якість (властивість) або комплексна характеристика особистості, що поєднує в собі бажання, готовність і здатність здійснювати діяльність (досягати поставленої мети, вирішувати проблеми, розв'язувати завдання, аналізувати ситуацію, приймати рішення, контролювати як власні, так і чужі дії, кваліфріковано та креативно реалізовувати потенціал тощо) у певній профресійній сфрері; на основі попередньо набутих компетенцій; компетенція - це сукупність знань, уявлень, умінь, навичок $і$ ставлень, що формуються в процесі навчання та застосовуються в певній сфері діяльності; професійна компетентність сукупність знань із професійно орієнтованих дисциплін (анатомія, фрізіологія, гістологія, фрармакологія тощо) $i$ вмінь їх практично використовувати в профресійній діяльності. Досліджено, що профресійно-комунікативна компетентність іноземного студента-медика - складна психолого-педагогічна категорія, яка, на нашу думку, інтегрує в собі профресійні знання (збір анамнезу, розпізнавання захворювання і встановлення діагнозу, призначення лікування тощо), самостійний і творчий склад мислення (уміння аналізувати процес, ефективність $і$ кінцевий результат лікування; уміння оцінити не лише досягнення у своїй роботі, але й побачити причини невдач), комунікативні уміння (володіння загальновживаною та професійною лексикою, правильний $і$ доречний добір мовних засобів, логічна і послідовна побудова висловлювання, відповідна дикція, вміння слухати, оформлення медичних документів: довідок, протоколу операції, історії хвороби чи рефрерату тощо), моральні цінності (толерантність, тактовність, терпіння, чуйність, співпереживання, толерантність, ввічливість, привітність, доброчинність тощо).

Ключові слова: 5-7 слів компетенція, компетентність, комунікативний, профресійний, профресійно-комунікативна компетентність, іноземний студентмедик.
\end{abstract}

